\title{
CONSTRUCT VALIDITY OF THE CAREER RESILIENCE QUESTIONNAIRE
}

\author{
GIDEON P DE BRUIN \\ Department of Psychology \\ University of Stellenbosch \\ CHARLENE C LEW \\ Department of Psychology \\ Rand Afrikaans University
}

\begin{abstract}
The construct validity of the Career Resilience Questionnaire (Fourie \& Van Vuuren, 1998) was investigated by means of an oblique multiple groups factor analysis. The highest factor structure coefficients of several of the items did not coincide with the respective factors that the items were postulated to measure. In addition, the correlations among the factors cast doubt on the independence of some of the constructs. The conclusion is drawn that a measure of career resilience should be based on an explicit theoretical measurement model rather than on an empirically derived measurement model. It is further recommended that the test items should have high face validity and content-saturation.
\end{abstract}

\section{OPSOMMING}

Die konstrukgeldigheid van die Career Resilience Questionnaire (Fourie \& Van Vuuren, 1998) is aan die hand van die gekorreleerde meervoudige-groeperingsmetode van faktorontleding ondersoek. Die resultate dui daarop dat verskeie items nie hulle hoogste faktorstruktuurkoëffisiënte op die gepostuleerde faktore gehad het nie. Verder het die korrelasies tussen die faktore daarop gedui dat die gepostuleerde konstrukte nie onafhanklik is nie. Die gevolgtrekking is gemaak dat 'n meetinstrument van loopbaangehardheid (career resilience) eerder op'n eksplisiete teoretiese metingsmodel gebaseer moet wees as op 'n empiriese verkreë metingsmodel.'n Verdere aanbeveling is dat die items oor'n hoë mate van gesigsgeldigheid en inhoudsversadiging moet beskik.

Fourie and Van Vuuren (1998) recently made an important contribution to the industrial psychology literature by constructing a measure of career resilience, namely the Career Resilience Questionnaire (CRQ). Their conceptualization of career resilience is largely built on the work of Gordon (1995) and London (1983, 1993). Career resilience refers to an ability to "bounce back" from adverse career related situations, and more specifically to resist career disruptions amidst less than ideal circumstances (Van Vuuren \& Fourie, 2000, in press). Fourie and Van Vuuren (1998) explain that career resilient individuals have the ability to adapt to changing circumstances. Such individuals are likely to welcome job and organizational changes, and find working with new and different people stimulating. Career resilient individuals are also recognized by their self-confident behavior and willingness to take careerrelated risks.

This focus on career resilience is in line with the increasing emphasis in mainstream psychology to search for indicators of physical and psychological well-being (Seligman \& Csikszentmihalyi, 2000; Strümpfer, 1999). Accordingly, Fourie and Van Vuuren (1998) constructed 60 items to measure career resilience. Referring to this Career Resilience Questionnaire they state: "Items reflect a career resilient disposition if the respondent exhibits a high degree of flexibility, adaptability, and competence despite adverse career situations" (Fourie \& Van Vuuren, 1998, p. 55). However, apart from this broad specification, no explicit theoretically derived multi-dimensional model of career resilience is given. In an endeavour to investigate the validity of the instrument, the 60 -item Career Resilience Questionnaire was administered to 352 workers (197 male and 155 female) from two different organizations. Fourie and Van Vuuren (1998, p. 55) describe the organizations as "predominantly white-collar", and heterogeneous in terms of their area of operation, as participants from secretarial, clerical, marketing, accounting and managerial functions were included in the sample.

Following the guidelines presented by Schepers (1992) for the factor analysis of items, Fourie and Van Vuuren extracted 20 factors from the intercorrelations among the 60 items. This

Requests for copies should be addressed to: GP de Bruin, Department of Psychology, University of Stellenbosch, Private Bag X1, Matieland, 7602. number of factors corresponded to the number of eigenvalues greater than one. The factors were rotated according to the varimax criterion. Next, scores for each factor were computed and the intercorrelations between the first order factors were subjected to a second order factor analysis. Six second order factors emerged. However, two of the second order factors were discarded because they were not "properly defined" (Fourie \& Van Vuuren, 1998, p. 55). The remaining four factors were labelled (a) Belief in oneself, (b) Disregard for traditional sources of career success, (c) Self-reliance, and (d) Receptivity to change. Thereafter, the items that were identified as indicators of each of the factors were subjected to an item analysis. The purpose of the item analysis apparently was to construct maximally reliable scales. Following the item analysis, Fourie and Van Vuuren (1998) retained 45 items: 14 items for Scale 1 (Belief in oneself), $\alpha=0.730$; seven items for Scale 2 (Disregard for traditional sources of career success), $\alpha=0.684$; nine items for Scale 3 (Self-reliance), $\alpha=0.617$; and 15 items for Scale 4 (Receptivity to change), $\alpha=0.717$. It is obvious that the reliability coefficients of the scales range from marginally satisfactory $(\alpha=0.730)$ to unsatisfactory ( $\alpha=0.617)$, suggesting that the items in the four scales are conceptually somewhat disconnected and not tightly clustered. Fourie and Van Vuuren (1998) also reported that the correlations among the four second order factors were low.

Given the importance of the resilience construct in career psychology, and the apparent need for a reliable and valid operationalization thereof, a further exploration of the underlying dimensions of the Career Resilience Questionnaire was warranted.

\section{The present study}

The aim of the present study was to investigate the construct validity of the Career Resilience Questionnaire by means of an oblique multiple groups factor analysis. Based on the findings of Fourie and Van Vuuren's (1998) factor analysis, a measurement model was postulated for 45 items, each of which relates to only one factor. This measurement model is reflected in Table 1.

Oblique multiple groups confirmatory factor analysis was specifically selected to evaluate the validity of this measurement model. This technique was originally developed by 
Guttman (1952), Holzinger (1944) and Thurstone (1945). Although the technique has been largely replaced by full information maximum likelihood and generalized least squares confirmatory factor analysis methods that are based on the analysis of linear structural relations (e.g. LISREL), it still provides one of the simplest and most efficient methods for item analysis and confirmatory factor analysis. Several elaborations of the merits of the oblique multiple groups method for item analysis may be found in more recent literature (see Gorsuch, 1983; Nunnally \& Bernstein, 1994; and Paunonen, 1987).

TABLE 1

POSTULATED MEASUREMENT MODEL OF THE CAREER RESILIENCE QUESTIONNAIRE

\begin{tabular}{ll}
\hline Factor & Items \\
\hline Factor 1 (Belief in oneself) & $1,2,3,9,12,13,19,27,28,28,36,40,42$, and 43 \\
Factor 2 (Own success ethic) & $10,26,32,34,35,38$, and 44 \\
Factor 3 (Self-reliance) & $4,8,16,23,24,33,37,39$, and 41 \\
Factor 4 (Receptivity to change) & $\begin{array}{l}5,6,7,11,14,15,17,18,20,21,22,25,30,31, \\
\text { and 45. }\end{array}$ \\
\hline
\end{tabular}

In an oblique multiple groups factor analysis each factor is simply defined as the unweighted sum of the standardized variables that are postulated to be indicators of the factor. Paunonen (1987) explains that "each multiple group factor could be identified with the centroid of the cluster of items belonging to each distinct scale ..." (p. 439). The oblique multiple groups factor analysis method provides confirming evidence of the validity of a measurement model if (a) items have high loadings on the factors they are postulated to measure, and if (b) items have low loadings on factors they are not postulated to measure. Disconfirming evidence is provided if (a) items do not have high loadings on the factors they are postulated to measure, and if (b) items have high loadings on factors they are not postulated to measure. These criteria reflect the ideal of simple structure. In addition, the oblique multiple groups technique provides estimates of the correlations between factors. Factors that correlate too high or too low, with respect to theoretical considerations, also provide disconfirming evidence regarding the factor structure of the variables of interest.

\section{METHOD}

\section{Participants}

The participants were 202 adults between the ages of 25 and 48 years (133 male and 69 female). Only three of the participants were unemployed. The participants represent a wide variety of organisations and fields of occupation. As many as $90,1 \%$ of the participants were functional in the broad field of business, and especially in the capacity of management. Most of the participants were recruited from a Masters of Business Administration programme. The remaining participants were recruited via the Human Resources departments of four different companies.

\section{Instrument}

The development and psychometric properties of the Career Resilience Questionnaire are described in the preceding paragraphs. The 45 items are presented as questions and the respondent indicates his or her answer to items on a seven-point Likert-type scale.

\section{RESULTS}

The estimated factor structure coefficients of the Career Resilience Questionnaire are given in Table 2. Each factor structure coefficient represents the correlation between the item and the factor represented by the particular column. Since the analysis was performed with iterated communalities in the diagonal of the correlation matrix, the correlation between any given item and its assumed factor was corrected for attenuation due to the unreliability of the item. Similarly the correlations among the factors were corrected for attenuation, and would be higher than the correlations between the scales.
TABLE 2

FACTOR STRUCTURE COEFFICIENTS OF THE CAREER RESILIENCE QUESTIONNAIRE ITEMS

\begin{tabular}{|c|c|c|c|c|}
\hline Item & Factor 1 & Factor 2 & Factor 3 & Factor 4 \\
\hline 1 & $\underline{43}$ & 07 & $\underline{32}$ & 37 \\
\hline 2 & $\underline{42}$ & -23 & $\overline{18}$ & 31 \\
\hline 3 & $\underline{48}$ & 06 & $\underline{33}$ & $\underline{44}$ \\
\hline 9 & 23 & -05 & -13 & -04 \\
\hline 12 & 28 & -25 & -01 & -05 \\
\hline 13 & $\underline{44}$ & 06 & $\underline{31}$ & $\underline{42}$ \\
\hline 19 & $\underline{36}$ & -25 & 18 & 16 \\
\hline 27 & $\underline{49}$ & -11 & 13 & 20 \\
\hline $28 \star$ & $\underline{39}$ & 08 & $\underline{42}$ & $\underline{38}$ \\
\hline 29 & $\underline{42}$ & $\underline{-30}$ & $-\overline{-02}$ & 04 \\
\hline 36 & $\underline{35}$ & -27 & 03 & 11 \\
\hline $40^{\star}$ & 28 & -16 & $\underline{33}$ & $\underline{31}$ \\
\hline 42 & 18 & 00 & 10 & 06 \\
\hline 43 & $\underline{46}$ & 08 & $\underline{32}$ & $\underline{31}$ \\
\hline 10 & -14 & $\underline{74}$ & 18 & 27 \\
\hline 26 & -07 & $\underline{56}$ & $\underline{35}$ & 27 \\
\hline $32^{\star}$ & $\underline{-34}$ & 06 & -09 & -23 \\
\hline 34 & $\overline{-22}$ & $\underline{39}$ & $\underline{33}$ & 09 \\
\hline 35 & -20 & $\underline{84}$ & 15 & 22 \\
\hline $38^{\star}$ & 07 & 01 & 22 & 20 \\
\hline $44^{\star}$ & 22 & 17 & $\underline{31}$ & $\underline{36}$ \\
\hline $4 \star$ & $\underline{38}$ & 04 & $\underline{45}$ & $\underline{51}$ \\
\hline 8 & 16 & 18 & $\underline{42}$ & $\underline{31}$ \\
\hline 16 & 00 & 23 & $\underline{31}$ & $\overline{14}$ \\
\hline $23 \star$ & $\underline{33}$ & 03 & $\underline{35}$ & $\underline{38}$ \\
\hline 24 & 18 & 15 & $\underline{46}$ & $\underline{40}$ \\
\hline $33^{\star}$ & 12 & 23 & $\underline{33}$ & 37 \\
\hline $37 \star$ & 12 & $\underline{33}$ & 25 & 36 \\
\hline 39 & -03 & 26 & $\underline{37}$ & $\overline{26}$ \\
\hline 41 & $\underline{38}$ & $\underline{38}$ & $\underline{52}$ & $\underline{40}$ \\
\hline $5^{\star}$ & 22 & 13 & $\underline{49}$ & $\underline{43}$ \\
\hline $6^{\star}$ & 29 & -14 & 06 & 14 \\
\hline $7 \star$ & 13 & 27 & $\underline{57}$ & $\underline{37}$ \\
\hline 11 & 15 & 27 & $\underline{39}$ & $\underline{48}$ \\
\hline 14 & 22 & 10 & $\overline{13}$ & 23 \\
\hline 15 & 24 & 17 & $\underline{50}$ & $\underline{58}$ \\
\hline 17 & 20 & -09 & 16 & 21 \\
\hline 18 & 16 & 27 & $\underline{49}$ & $\underline{52}$ \\
\hline 20 & $\underline{35}$ & 21 & $\underline{46}$ & $\underline{55}$ \\
\hline 21 & 02 & 21 & 27 & $\underline{33}$ \\
\hline $22^{\star}$ & $\underline{47}$ & 04 & 26 & $\underline{40}$ \\
\hline $25^{\star}$ & $\underline{40}$ & $\underline{43}$ & $\underline{64}$ & $\underline{51}$ \\
\hline 30 & 25 & $\underline{35}$ & $\underline{43}$ & $\underline{62}$ \\
\hline 31 & 16 & 19 & 25 & $\underline{41}$ \\
\hline $45^{\star}$ & 29 & 21 & $\underline{44}$ & $\underline{38}$ \\
\hline
\end{tabular}

Note. Decimal signs are omitted. All factor structure coefficients greater than or equal to 0.30 are underlined. Items that have their highest factor structure coefficient on a wrong factor are marked with an asterisk. The item numbers of items that fail to have a factor structure coefficient greater than or equal to 0.30 on their postulated factors are printed in boldface.

The internal consistency reliability coefficients of the four factors are: Factor $\mathrm{I}=0.692$, Factor II $=0.532$, Factor III $=0.608$, and Factor IV $=0.750$. The reliability coefficients of three factors for the present sample are lower than those reported by Fourie and Van Vuuren. However, for Factor IV the reliability coefficient is slightly higher. Overall, the reliability of the factors can only be described as unsatisfactory.

Inspection of Table 2 reveals a very complex factor solution. The highest factor structure coefficients of fifteen of the 45 items $(33.33 \%)$ were obtained for factors the items were not postulated to measure. In addition, 11 items $(24 \%)$ failed to have factor structure coefficients greater than or equal to 0.30 on their postulated factors. Furthermore, Table 2 shows that several items are factorially complex, having more than one salient factor structure coefficient. The correlations between the pairs of factors are reflected in Table 3 . Since use has been made of communalities, these correlations reflect the relationships among the latent constructs that the factors represent. The cor- 
relation between Factors III and IV is indicative of the fact that these factors do not represent separate constructs $(r=0.90)$.

TABLE 3

INTERCORRELATIONS OF THE

CAREER RESILIENCE QUESTIONNAIRE FACTORS

\begin{tabular}{lrccc}
\hline & Factor 1 & Factor 2 & Factor 3 & Factor 4 \\
\hline Factor 1 & 1.00 & & & \\
Factor 2 & -0.25 & 1.00 & & \\
Factor 3 & 0.48 & 0.53 & 1.00 & \\
Factor 4 & 0.58 & 0.43 & 0.90 & 1.00 \\
\hline
\end{tabular}

\section{DISCUSSION}

The results presented above show that the four factors postulated by Fourie and Van Vuuren (1998) provide an unsatisfactory explanation of the correlations among the 45 items of the Career Resilience Questionnaire. Hence, the construct validity of the Career Resilience Questionnaire is not supported. Three possible reasons for this are presented. Firstly, Fourie and Van Vuuren (1998) identified and described the factors of the Career Resilience Questionnaire after the fact. In other words, their factors do not conform to an a priori multidimensional theory of career resilience. Rather, the factors were empirically derived and are therefore data-driven rather than theory-driven. The possibility remains that such empirically derived factors may have capitalised on chance factors or peculiarities of the participants involved. It is important to note that Fourie and Van Vuuren's (1998) participants came from only two organisations and that the identified factors may well be unique to those two settings. In contrast, the participants in the present study represent a wide variety of organisations.

Secondly, the formulation of the items may be improved. In general, the items are long and cumbersome. Several items also present more than one aspect that the respondent has to take into consideration in order to give an answer. Examine, for instance, item 22: "How confident do you feel to openly express your ideas in any work setting even if they are unpopular?" A more efficient and easily comprehended item might possibly be: "How confident are you of expressing unpopular ideas at work?"

Thirdly, the content of many items appear to be distant from the core meaning of the career resilience construct. For instance, it is not clear how item 13 relates to the ability to resist career disruptions or "bounce back" from adverse career situations: "To what extent have you introduced a new method, product or procedure in your current job?” One would expect that some reference be made to adverse career situations in all the items. However, this is not the case for several items. Three examples are given below:

Item 7: How willing would you be to change employers frequently in order to advance your career?

Item 8: To what extent would you make use of contacts like key customers/suppliers to gain access to new job opportunities?

Item 38: How important do you regard it that an employer should try to keep people in his service for as long as possible?

Jackson and his co-workers (Holden \& Jackson, 1979; Holden, Fekken \& Jackson, 1985) have demonstrated that the validity of items and scales are improved if the items are content-saturated. Content-saturated items closely reflect the core of the construct being measured and are likely to have high face validity. Such items appear to provide better measures than items that are not face valid (Holden \& Jackson, 1979).

The criticisms given above do not negate the valuable contribution to the career resilience literature that Fourie and Van Vuuren (1998) have made, but rather underline the need for the revision and further development of the Career Resilience Questionnaire. In this regard it is recommended that an explicit theoretically derived hierarchical multi-dimensional model of career resilience should be developed. At the highest level of the hierarchy a general career resilience factor should be defined. At the lower level the theoretically derived subdimensions of career resilience should be incorporated. Items may then be generated for each of these dimensions. It is recommended that the items should be short and simple. The items should also have face validity and demonstrate contentsaturation. Such items may then be subjected to an item factor analysis with the explicit aim of identifying the items that are the best indicators of the theoretically derived dimensions of career resilience.

\section{ACKNOWLEDGEMENT}

We gratefully acknowledge the assistance of Prof. Zak Nel in the collection of the data for this study.

\section{REFERENCES}

Fourie, C., \& van Vuuren, L.J. (1998). Defining and measuring career resilience. Journal of Industrial Psychology, 24 (3), 52-59.

Gorsuch, R.L. (1983). Factor analysis (2nd edition). Hillsdale, NJ: Lawrence Erlbaum.

Guttman, L. (1952). The multiple group methods for common-factor analysis: Their basis, computation, and interpretation. Psychometrika, 17, 209-222.

Holden, R.R., \& Jackson, D.N. (1979). Item subtlety and face validity in personality assessment. Journal of Consulting and Clinical Psychology, 47, 459-468.

Holden, R.R., Fekken, C., \& Jackson, D.N. (1985). Structured personality test item characteristics and validity. Journal of Research in Personality, 19, 386-394.

Holzinger, K.J. (1944). A simple method of factor analysis. Psychometrika, 9, 257-262.

London, M. (1983). Toward a theory of career motivation. Academy of Management Review, 8, 620-630.

London, M. (1993). Relationship between career motivation, empowerment and support for career development. Journal of Occupational and Organizational Psychology, 66, 55-69.

Nunnally, J.C., \& Bernstein, I.H. (1994). Psychometric methods (2nd edition). New York: McGraw-Hill.

Paunonen, S.V. (1987). Test construction and targeted factor solutions derived by multiple groups and Procrustes methods. Multivariate Behavioral Research, 22, 437-455

Schepers, J.M. (1992). Totskonstruksie: Teorie en praktyk. Johannesburg: RAU-Drukpers.

Seligman, M.E.P., \& Csikszentmihalyi, M. (2000). Positive psychology: An introduction. American Psychologist, 55, 514.

Strümpfer, D. (1999). Psychological resilience in adults. Studia Psychologica, 41, 89-194.

Thurstone, L.L. (1945). A multiple group method of factoring the correlation matrix. Psychometrika, 10, 73-78. 


\title{
REJOINDER TO ARTICLE BY DE BRUIN AND LEW: CONSTRUCT VALIDITY OF THE CAREER RESILIENCE QUESTIONNAIRE (CRQ)
}

\author{
LJ VAN VUUREN \\ C FOURIE \\ Programme in Industrial Psychology \\ Department of Human Resource Management \\ Rand Afrikaans University
}

\begin{abstract}
This rejoinder is presented in response to an analysis by De Bruin and Lew of the 1998 publication by Fourie and Van Vuuren on the career resilience construct. Comments and recommendations made by De Bruin and Lew in respect of the construct validity of the CRQ are responded to in terms of the theoretical foundation of the CRQ, the methodology used, the CRQ's content validity, sample-related issues, the instrument's construct validity, as well as a perspective on the future of the instrument.
\end{abstract}

\section{OPSOMMING}

Hierdie repliek word voorgehou na aanleiding van'n ontleding deur De Bruin en Lew wat op die 1998 -publikasie van Fourie en Van Vuuren aangaande die konstruk loopbaangehardheid, gebaseer is. Respons op die kommentaar en aanbevelings deur De Bruin en Lew aangaande die konstrukgeldigheid van die Loopbaan-gehardheidsvraelys (LGV) word voorgehou in terme van die teoretiese basis van die LGV, die metodologie wat gebruik is, die inhoudsgeldigheid van die LGV, die instrument se konstrukgeldigheid, steekproefverwante vraagstukke, asook 'n perspektief op die toekoms van die instrument.

A major concern for individuals pursuing careers in less than optimal career conditions within the new career paradigm is the enhancement of employability inside and outside their present employers' contexts. The phenomenon career resilience, of which the opposite condition appears to be career vulnerability, may be a critical competency of individuals to overcome adverse circumstances that impact career deployment and employability.

Since the career resilience concept is a relatively "new entrant" to the field of career management, any effort to contribute to the scientific exploration of career resilience is deemed to enhance the understanding of the theoretical framework of career resilience theory and imminent operationalisation thereof. The opportunity to respond to the special effort made by De Bruin and Lew in this regard, is therefore appreciated. Although each attempt at exploring and clarifying a construct such as this may contribute to its body of knowledge, it should, however, be borne in mind that the results of the studies on career resilience as referred to in this rejoinder, may all be regarded as sample-specific. Cross-validation is therefore ultimately required.

At he time of publication Fourie and Van Vuuren (1998) were fully aware of the need for further exploration of their findings by stating that "there are certain limitations to generalising and interpreting the findings of the study. In the first instance, the construct of career resilience is a complex phenomenon and research and inquiry into the nature thereof are not conclusive. Secondly, the reliability and validity of the Career Resilience Questionnaire (CRQ) as measuring instrument, have not been substantiated conclusively" (p. 58). This reinforces the scientific notion that no instrument is a constant - the continued development thereof is a function of continuous reciprocation between theory, research and practice. Blind empiricism is therefore not really an option when a construct like career resilience, and the CRQ as its descriptive measure, is scrutinised.

It has to be pointed out that the terms of the initial agreement on gaining access to and administering the CRQ, Lew (the second author) was explicitly alerted to the exploratory nature

Requests for copies should be addressed to: LJ Van Vuuren, Programme in Industrial Psychology, Department of Human Resource Management, RAU, PO Box 524, Auckland Park, 2006. of the Fourie and Van Vuuren (1998) study, and that the CRQ was still in the process of being validated. It was further agreed that findings and results would be shared. The De Bruin and Lew commentary therefore came as no surprise, since it was prompted by Fourie and Van Vuuren. De Bruin and Lew's work is viewed as a contribution that will certainly add value to the on-going analysis of the theoretical and statistical properties of the career resilience construct.

In response to De Bruin and Lew's findings, some comments regarding the theoretical foundation of the CRQ, the methodology used, the CRQ's content validity, sample-related issues, the instrument's construct validity, as well as a perspective on the future of the instrument, is provided henceforth.

\section{Theoretical foundation of the CRQ}

At the time of the Fourie and Van Vuuren (1998) study, the earlier research on resilience as a construct that may have application in the field of career management, was limited. Nor was there an instrument to measure career resilience more comprehensively than the seven- and 13 item-approaches by London (1983, 1993) and Noe, Noe and Bachhuber (1990) provided for. London (1983), in his initial exploration of the concept, conceded that the dimensions of career resilience are neither independent nor necessarily exhaustive of all possible important constructs. In confirming London's initial reservations, De Bruin and Lew allude to the fact that "no explicit theoretically derived multi-dimensional model of career resilience is given" in the Fourie and Van Vuuren (1998) article. The latter research report was, however, based on the, albeit few, efforts of Bridges (1995), Gordon and Coscarelli (1996), London $(1983,1993)$ and Noe, et al. (1990), who pioneered attempts to describe and delineate the construct in terms of its importance and utility.

The intention with the 1998 study by Fourie and Van Vuuren was not to develop such a model, but to explore the concept that was originally coined by London (1983) as a dimension of his multidimensional theory of career motivation. In line with this aim it was decided to define and describe career resilience within the new career paradigm, and to develop a measuring instrument that may enable the researchers to shed more light on the concept than initial London $(1983,1993)$ and Noe, et al. (1990) findings allowed for. 